\title{
The Legal Effect of the Absence of Mentioning the Name of the Opponent's Name in the Letter of Attorney
}

\author{
Mohammad Mahjoob Almaharmeh ${ }^{1}$ \\ ${ }^{1}$ Sheikh Noah College of Sharia and Law, The World Islamic Sciences and Education University, Jordan \\ Correspondence: Mohammad Mahjoob Almaharmeh, Sheikh Noah College of Sharia and Law, The World Islamic \\ Sciences and Education University, Jordan. E-mail: Mohammad.Almaharmeh@wise.edu.jo
}

Received: August 6, 2021

Accepted: August 31, 2021

Online Published: September 1, 2021

doi:10.5539/jpl.v14n4p93

URL: https://doi.org/10.5539/jpl.v14n4p93

\begin{abstract}
The current study aims to research in the matter of not mentioning of the opponent's name in the power (letter) of attorney contract, and whether this fault is considered as a professional mistake. This is because the lawyer care is different from the ordinary man in the field of his profession that attributes to his knowledge in his profession rules and bases, so; the care required of him is completely different from that of an ordinary man, and in this case the foolishness is considered as a professional mistake that affect the validity of the letter of attorney and as a result a validity of the issued ruling in the case. To achieve the aims of this study the researchers apply the analytical paradigm that investigates the legal texts and judicial rulings with regard this problematic.
\end{abstract}

Keywords: attorney, letter of attorney, foolishness

\section{Introduction}

The agency contract is one of the so-called contracts for which the Jordanian legislator singled out provisions for it in Chapter Three of the Civil Code. There is a text stating otherwise, and what is meant by the agency contract is to specify the name of the principal with an indication of the type of his agency, as well as the commission that he will receive for the work he was entrusted with, with an indication of its percentage and the penal conditions resulting from violating his obligations, all taking into consideration in the agency contract the provisions of the local law of the country of the agent (sanhory, 1989, 486).

The agency contract, like all other contracts, must be consensual between the offer and acceptance between the principal and the agent, so they agree on the nature of the contract. With regard to the attorney's agency, it grants him the right to attend on behalf of the concerned persons before the police departments, the Public Prosecution, and the judicial and administrative committees with judicial jurisdiction, as well as the arbitral tribunals and courts of their degrees, which is what was stated in Article 36 of the Unified Arab Law for Advocacy for the year 2002 AD. Consequently, it may sometimes happen that the judgment or decision be caused by a material error that would affect the judgment issued in the case, and the material error is meant by errors in writing, error in arithmetic, numbers, symbols, error in expression, or omission to mention a party in the litigation during the judgment and edit it.

\section{Research Problem and Objectives}

The problem of this study centers on the statement of the position of the Jordanian legislator regarding the loss of the name of the opponent in the attorney's power of attorney and the extent of the legal effect in this case. Research on this problem requires the researcher to answer the following sub-questions:

1) Indicating the nature of the agency contract by stating its concept, conditions, pillars and ways of rescinding it according to the Jordanian Civil Code?

2) A statement of the errors that may occur in the attorney's agency and their legal effect?

\section{Research Methodology and Plan}

In this study, the researcher relied on the descriptive analytical approach, which is concerned with the study, analysis and description of phenomena in an objective and accurate manner, by clarifying the provisions of the Jordanian law and the decisions of the Jordanian Court of Cassation. On the subject of the study, then analyzing it and clarifying its shortcomings and weaknesses, with weighting and expressing an opinion. Therefore and in order 
to achieve the objectives of this study by studying the statement of the nature of the agency contract, its conditions and pillars in the first topic, and discussing the errors that may occur in the attorney's agency and the legal consequences thereof in the second topic.

\section{The First Topic: The Concept of Agency Contract}

In this topic, a number of legal issues related to the agency contract will be addressed by clarifying the concept of the agency contract (the first requirement). In the second requirement, the elements and conditions of the agency contract will be discussed, and at the end of this topic, the cases in which the agency contract ends (the third requirement) will be indicated.

\subsection{The First Requirement: The Concept of Agency Contract}

Agency originally means delegation, and I delegated it, that is, I delegated the matter to God. God's saying: (And you will remember what I [now] say to you, and I entrust my affair to Allah. Indeed, Allah is Seeing of [His] servants) ${ }^{1}$. And: (to You we have returned, and to You is the destinationur affairs to you .That is, we delegated $\mathrm{o}^{2}$ ) and returned to you in every distress and need. (Ibn Kathir, 1400, 338). As stated in Al Basatani (1990, 718) Agency comes in the sense of preservation, as God said : (they said, God is enough for us, and He is a good doer) ${ }^{3}$.

And the meaning of dependency in their saying that a person puts his trust in God means reliance on him and reliance on him. And the name is Menna Al-Taklan (Fayoumi, 1922, 670). Dependence is a manifestation of helplessness or weakness and dependence on others (Razi, 1865, 429). And the meaning of dependency, as someone who said: People depend, that is, some of them depend on each other until they missed what is required (Fayoumi, 1922, 670, Razi, 1865, 429).

As it came in Lisan al-Arab from the names of God the Guardian: He is the resident who takes care of people's livelihood, and his reality is that he is independent of the matter entrusted to him. (Ibn Manzur, 1290). Allah says: (not take other than Me as Disposer of affairs). The mouse said: It is called usury, and it is said that it is sufficient. Al-Anbari said: It was said Al-Wakeel Al-Hafiz.

Agency is legitimate in the Book, the Sunnah of the Prophet and the consensus, and from that is the Almighty's saying in His Mighty Book: (Send one of you with these papers of yours to Medina, so let him see which of you has the best taste, and let him bring you sustenance from him) ${ }^{4}$. As for the Sunnah of the Prophet, it was narrated by Abu Dawood with a chain of narration on the authority of Jabir bin Abdullah, and he said: I wanted to go out to Khaybar, so I came to the Prophet, may God bless him and grant him peace. Peace be upon him. He said: I want to go to Khaybar. He said: You are my agent, Take fifteen plasters from him, and if he wants a sign, put your hand on the wishbone. (Maqdisi, 1971,201). The evidence from the hadith is that it indicates the validity of the agency and that the imam has the right to authorize and delegate to take the charity and pay it to those who deserve it and who sends it. He has leadership, and that the agency is signed by the Messenger by his work, this indicates the legitimacy of the agency, otherwise it would have been what he, may God's prayers and peace be upon him, did.

Agency has been defined in Islamic law as "a contract under which a customer establishes another person to replace himself in a known permissible conduct." 5

Al-Ahnaf described it as delegating the disposition of the agent and preserving it (Al-Kasani, 1402, 19), It has been defined as: "It is to put another person in his shoes in a known permissible conduct (Al-Zayli, 1314, 254)". The disposal includes financial transactions such as buying and selling and everything that the prosecution accepts according to Sharia, such as the entry permit (Al-Zuhaili, 1984, 72). The Malikis also defined it as "a representative of the owner of a right who neither commands nor worships others in it" (Al-Azhari, 1997, 125), and the Shafi' is defined it as "the authorization of one person to another to do this.). Finally, the Hanbalis defined it as "the representation of a person that it is permissible to act in the same manner as the representative (Al-Bahooti, 1982, 1402)."

Legally, Article (833) of the Jordanian Civil Code defines an agency contract as "a contract in which the principal establishes another person to replace him in a known and permitted business ${ }^{6}$." The original place of the agency

\footnotetext{
${ }^{1}$ Ghafir 44,

${ }^{2}$ Al mumtahinah, 4

${ }^{3}$ Al-Imran, 173

${ }^{4}$ Al-Kahf, 19

${ }^{5}$ Journal of Judicial Judgments in Articles (1459, 1449).

${ }^{6}$ This text complies with Article (924) of the Civil Transactions Law in the United Arab Emirates, Article (416) of the Sudanese Civil Transactions Law, Article (927) of the Iraqi Civil Code, and Article (689) of the Kuwaiti Civil Code.
} 
according to this definition is always the permissible and known act, and the source of the ruling in this text is Article (1449) of the Code of Judicial Judgments, which states that "the agency delegates someone to the job." from the other, and fixing it in place at that job." It is said that a person is delegated to him, and he whom he appoints is an agent, and for this reason he is entrusted with him. As stated in the decision issued on 16/6/2009 by the Jordanian Court of Cassation in its human rights panel No. 1198/2009, "The agency is a contract whereby the client establishes another person in his place in a permissible and known manner, and that the management, preservation and legal actions that the client may perform are valid. To be the subject of an agency contract, And that its scope expands to include management, preservation, and other legal acts of compensation and donations in the absolute agency, and narrows it down to be limited to a specific work or assignable, denying ignorance in the restricted agency. Except for the works of management and preservation, and if they are allocated to a specific legal action, they are limited to its scope However, if it is absolute and does not have a definite specific place, it includes any place of the client except for donations, as they must be declared, and that the agent is obligated to carry out his agency without exceeding its limits except in respect of specific matters in which the necessary consequences are required by their nature. It also benefits from the provisions of Articles 833-867 of the Civil Code." (Nader.2015 10).

Through these definitions, we conclude that power of attorney in litigation is "authorizing one person to another to take over the case for himself initially or respond to it with opposition, before the competent court, in a known act subject to the representation of the one who owns it, not conditional on his death (Al-Ani, 1965, 50)". The meaning of the phrase "replaces" is that the agent is making an effort to protect the rights of his client, as if doing so for himself, he is making every effort to protect his rights. The term "initiation" or "objection" also means that when his client assumes the capacity of the plaintiff, he presents the case on his behalf, presents evidence and seeks judgment for his client, or when his client assumes the capacity of the defendant and then denies the case and challenges the witnesses to claim the acquittal of his client (Bani Mustafa, 2012, 49). Accordingly, the agency contract is considered a consensual contract, and it is sufficient to conclude it only by matching the will of the principal and the agent without the need to invalidate it in a specific form (Shaheen, 2013, 28). Therefore, it is sufficient to offer and accept, whether in writing or verbally. The purpose of writing the contract is to prove it and not to conclude it, and the principle of consent is excluded from what is stated in the Jordanian Civil Code. Procedures Law No. (24) of 1988 regarding the attorney's agency, where Article 63 states in its second paragraph that "the agent must prove his agency on behalf of his client with an official document if his agency is public, and if his agency is private and unofficial, then it must be certified by the signature of the director.

The agency contract is also characterized as one of the contracts binding on two parties based on the personal consideration of the two parties to the contract, namely the principal and the agent, where each accused takes the personality of the other into consideration ${ }^{7}$, thus, each party has obligations that it must abide by vis-à-vis the other. Obligations in contracts binding on both sides arise simultaneously at the time of the conclusion of the contract. The client may waive the agency before completing the legal disposition in place of the agency (Sultan, 2016, 151). Thus, Article (699) of the Egyptian Civil Code stipulates that "the agency is a contract in which the agent is obligated to perform legal work for the account of the principal." Although the agency contract is described as a binding contract for two parties, the agency may be binding on the agent alone, and the principal is not obligated if this agency is without remuneration, and the agent has not incurred any expenses, and he has not been harmed as a result of performing the work entrusted to him. Therefore, the agency contract is originally considered a donation contract unless otherwise stipulated explicitly or implicitly between the two parties (El-Shahawi, 2001, 78-79). In this regard, Article (857) of the Jordanian Civil Code stipulates that the agency is one of the contracts of compensation, if the two parties agree that it is paid, or the agent is among those who work for wages, as if the agent's work is one of the work of his profession as the commission agent (Nader, 2015, 28).

Agency depending on its source is either agreement, legal or judicial. An agreement agency is the one whose source is the consent of the contracting parties, and a legal agency is the agency derived from law, such as the agency of a trustee. A judicial agency is one that is decided by the judiciary, although in reality it is considered a type of legal agency. Because the judge appoints the agent based on the text of the law, meaning that the agency in this case is also derived from the law (Abd al-Rahman, 2009, 129).The agency may also be public or private, as Article (836) of the Jordanian Civil Code stipulates that "the agency is private if it is limited to a specific matter or matters and is general if it includes every matter that accepts the representation:

1) If it is private, the agent has no other choice but to undertake the matters specified in it and the necessary

\footnotetext{
${ }^{7}$ Article (843) of the Jordanian Civil Code. See also: Abdul Razzaq Al-Sanhouri, Contracting Works Contracts, Agency, Deposit and Guard, Vol. 7, Arab Renaissance Publishing House, Cairo, p. 375.
} 
consequences related to it that are required by the nature of the actions entrusted to it.

2) If it is general, the agent may initiate compensation and disposals, except for donations, which must be declared.

This text corresponds to what was stated in Article (1987) of the French Civil Code, which indicated that the agency is either specific to a specific case or to several specific cases, or it is general so that it deals with all cases of the client (Yaken, 1996, 83-84). The general agency is mentioned in general terms in which the principal does not specify the subject of the legal disposition entrusted to the agent, so the principal says to the agent, for example, "I have assigned you to manage all my business," or "I have delegated you to manage my locality" and other such expressions that are contained in general terms, not specification. In which. Whether the general agency includes management activities or not, it does not authorize the agent with capacity except to carry out management work, and therefore the agent may not perform any act of disposal, whether it is a donation or compensation, unless the nature of the disposal requires otherwise, and then The agent in the general agency may not donate or sell any money owned by the principal, nor participate in it, nor lend it, reconcile over it, judge it, or mortgage it, or create any original right in rem on it, or result in any right in kind except If it is agreed upon (Abd al-Rahman, 2009, 133).

Article (702) of the Egyptian Civil Code also referred to the special agency when it stipulated "1. A special power of attorney is required in every non-administrative act, especially in selling, mortgaging, donations, conciliation, approval, arbitration, oath, and pleading before the judiciary. 2. A special agency in a certain type of legal business is valid even if the place of this work is not specifically specified, unless the work is from donations 3. A special agency does not give the agent a direct capacity except in carrying out the matters specified in it, and these matters are not required by these matters. the necessary consequences according to the nature of each matter and current usages." According to this provision, disposal business must require a private agency, and a public agency may not, because of the seriousness or seriousness of such acts. It is not permissible for any person to authorize the last act of disposition, without specifying certain types of such disposition. The agent does not have the power to do any of these acts (acts of disposition), so permission is required from a private agency for each act of disposition, so the private agency is in selling, buying, endowing, paying the share in the company, lending or conciliation (Abd al-Rahman, 2009, 144).

\subsection{The Second Requirement: The Elements and Conditions of the Agency Contract}

Like all other contracts, the agency contract requires the availability of a number of elements for its validity. In addition, it requires the availability of a number of conditions, where the agency is held with the availability of three elements: consent, place and reason, in addition to the necessity of the eligibility condition in both the client and the agent, which will be discussed in this requirement as follows.

\subsubsection{First: Elements of the Agency Contract}

The Jordanian Civil Code requires the availability of a number of elements in order for the agency contract to be valid. These items are:

\subsubsection{Consensual}

In order for the agency contract to be concluded, the contract conditions represented by the offer-acceptance agreement, as well as the healthy conditions of free and sound will untainted by any defects must be met (AlSarhan, 2001, 112). The parties to the contract agree when they agree on the nature of the contract and the procedure required (Sanhouri, 1989, 486). Wages must be agreed upon, For example, in the attorney's agency contract, the attorney receives his fees in accordance with the contract concluded between him and the client, provided that the compensation for these fees does not exceed $25 \%$ of the real value of the dispute, except in exceptional cases that are assessed by the Council of the Syndicate, and if the fees are not determined in this way, it is determined by the Council of the Syndicate This is what is stipulated in the first and second paragraphs of Article (46) of the Law of the Bar.

Expression of consent is express or implied, provided that the consent of the principal precedes the act of the agent. The agent's consent can also be express or implied, provided that it was given prior to an incident that would terminate the agency if it were held. Implementation of agency is an example of tacit acceptance, and the agent's silence is tacit acceptance if the agency relates to acts that are incompatible with his or her profession such as a lawyer (Al-Sarhan, 2001, 113).

\subsubsection{His Position}

Article 843 of the Jordanian Civil Code states that agency must be feasible in order to be implemented, be specific, and legally permitted. If it cannot be implemented and done, then this means that its implementation is impossible, and what is meant here is an absolute impossibility, as Article 159 of the Jordanian Civil Code stipulates that "if 
the place is impossible in itself at the time of the contract, the contract is void", for example it is not permissible to appoint a lawyer to challenge a court ruling after the time for appeal has passed, or to appeal a ruling that is not subject to appeal (Al-Sarhan, 2001, 120). Therefore, any damage to the client as a result of this power of attorney entails the responsibility of the attorney for the damage.

\subsubsection{The Reason}

The Jordanian legislator specified the reason as the direct purpose intended for the contract, and stipulated that the contract be present, valid and permitted and not inconsistent with public order and public morals (Al-Far, 2018, 90). These reasons may be multiple in one commitment, where a person appoints a lawyer and the reason is his ignorance of the law or his inability to pursue the case, or because of the collection of debts from others in his favor, or to provide a motive. Others cannot provide it, or because the client is determined to travel outside the country, act as an agency, and claim in his absence, as if he is presents doing the work entrusted to him by one of the authorized agents or lawyers (Shams, 2001, 377).

\subsubsection{Second: Conditions for the Validity of the Agency Contract}

The conditions of validity of the agency are the conditions of validity of any other contract, where the eligibility in the contract and the safety of mutual consent from defects of management (Sanhouri, 1989, 486). In this aspect, we will discuss the eligibility of principal and agent as follows:

\subsubsection{Eligibility of the Principal}

It is required that the client be the owner of the right to dispose of what is entrusted to him, as Article (834) of the Jordanian Civil Code stipulates that "It is a condition for the validity of the agency that the client is the owner of it. The right to dispose of what is entrusted to him", Accordingly, if the agent disposes of something himself, then this disposition - and the case is one - is valid when another person is assigned to him, because the agent has the right to act on the part of the agent, so the customer must be the owner so that someone else owns it, and the lesson is in the availability of Capacity is the time of its convening and the time when it is acted together (Al-Sarhan, 2001). Accordingly, if the client is not qualified to act in the place of the agency, or the disposition is something in which the behavior of the client is not valid, then the agency is void (Sabre, 1998, 106).

\subsubsection{Eligibility of the Agent}

The agent must be distinguished, according to the general rules, even if he is a minor, because he expresses his will, and not the will of the principal (Sabre, 1998, 113), as it is not required that the agent be an adult, so it is correct for the discerning boy to be an agent even if he is not authorized. Rather, he is incompetent, just like the madman who does not represent him according to the general rules ${ }^{8}$. As for the lawyer, he requires a number of special conditions regulated by the Law of the Bar Association, where Article (7) of the law stipulates that the lawyer is registered in the teachers' register, and therefore cannot be appointed. A trained lawyer, as Article (80) specifies the conditions that the lawyer must fulfill. Registration is requested in the Lawyers Register, as it stipulates that he be of Jordanian nationality, that he be twenty-three years of age, and that he be of full legal capacity.

\subsection{The Third Requirement: Ways to Terminate the Agency Contract}

There are several ways in which agency ends. The agency contract may be terminated starting from the completion of the work entrusted to it. If the agency contract is a sale, the agency ends with the completion of the sale. The attorney's agency ends with the end of what the attorney has entrusted with filing a lawsuit, appeal, appeal, litigation, retrial, or all the above-mentioned works in accordance with the contract and the works entrusted to the attorney (Shams, 2001, 629). Agency also ends with the death of the agent or principal ${ }^{9}$. This is because the personality of the principal and the agent is considered (Pasha, 2005, 522), as Article (862) of the Jordanian Civil Code indicated that the agency ends with the death of the principal or the death of the agent. The agency contract ends with the agent's dismissal at any time. Here, if the agency is paid, the agent in this case is obligated to compensate the principal for the damages incurred as a result of this assignment in an inappropriate and unjustified excuse $^{10}$, Or for the principal to dismiss the agent, and the reason for this is that the agency was originally determined in the interest of the principal, and therefore the principal may dismiss the agent at any time ${ }^{11}$. Article

\footnotetext{
${ }^{8}$ See Murshid al-Hiran to know the human condition of the late Muhammad Qadri Pasha, third edition, Amiri Press 1909, Article (916). - The Journal (Judgement of Judicial Judgments) - Article (1458).

${ }^{9}$ See Article (714) of the Egyptian Civil Code, Article (680) of the Syrian Civil Code, and Article (946) of the Iraqi Civil Code.

${ }^{10}$ See Article (716) of the Egyptian Civil Code and Article (682) of the Syrian Civil Law.

${ }^{11}$ See Article (517) of the Egyptian Civil Code.
} 
(863) of the Jordanian Civil Code stipulates that "the principal may dismiss his agent whenever he wishes, unless the agency relates to the right of others or was issued in favor of the agent, and in this case: the principal may not terminate or restrict it without the consent of the person in whose favor it was issued." Finally, the agency expires with the expiry of its fixed term. Each agent or principal may specify a specific term for the agency to be terminated. If the period has expired and the work entrusted to the agent has ended, there is no objection to that, but if the time is up and the work is not over, here the first problems begin. If the client remains silent until it is completed, there is nothing wrong with that, but if a dispute arises as a result of this discrepancy, then the concerned judge is the one who evaluates the rights, effects and obligations arising from that. From this default (Shams, 2001, 630).

\section{The Second Topic: Mistakes That Occur in the Attorney's Agency}

After we explained in the previous section the concept of the agency contract, its pillars and conditions, we must come in this topic to the research problem, which is based on the legal effect of the lawyer without mentioning the name of his client's opponent in an agency. The question that comes to mind is that not mentioning the name of the litigant in the agency is a simple mistake that leads when issuing the judgment to refer to the court that issued the judgment and demand that the material error be corrected? Or is this mistake considered a mistake that is not easy and results in the invalidity of the judgment, since what happened in not mentioning the name of the opponent was due to gross ignorance that affected the validity of the judgment?

First of all, the attorney, in preparing the agency, may fall into a number of errors which may be categorized in terms of intentional errors which may be intentional or unintentional. The lawyer's mistake is intentional when an act is issued by the lawyer and his will is directed to achieve a specific result of harming others (Sultan, 2016, 263), while it is unintentional when directing his will to the act. Without intent to harm others (Althun, 2006, 181). His error can also be classified as an ordinary or professional error in terms of its relationship with the principles of the profession, so the lawyer's error is natural when he commits a material act that violates the duty of care and diligence imposed on all persons (Mansour, 2000,14), where the lawyer was asked about his usual mistake. For him, the criterion of deviation is the norm of the average person (Sultan, 2016, 342). While the lawyer's mistake is professional when it comes to the technical principles of the profession (Hussain, 1993, 342) and his professional and technical personal standards among lawyers (Sultan, 2016, 343), and issued by the lawyer. During the exercise of his profession, which results in violating the laws and regulations or being ignorant of them, It also includes every breach of duties, morals, traditions and binding rules of conduct or breach of decency, honor, honesty and integrity to which the customer is exposed as a result of a physical or moral act. The lawyer is subject to the general rules that are based on the basis that any harm to others requires the lawyer to redress it according to the usual lawyer's standard (Hussain, 1993, 342). The Jordanian legislator did not stipulate special rules that exclude the lawyer from the provisions of the general rules stipulated in the Jordanian Civil Code, Article 358 states that "If the debtor is obligated to keep the thing, to carry out his will or to exercise caution in carrying out his obligation, he will have fulfilled the obligation, if in carrying it out all the care of an ordinary person will be exercised. It will be exercised, even if it is not fulfilled. The intended purpose is achieved. Unless otherwise provided by law or agreement. Accordingly, the lawyer's failure to mention the name of the opponent's client in the power of attorney, or what may be called obscene ignorance, can be considered among the errors that must have a legal effect, whether in the validity of the judgment issued in the case. Or even on the rights of the client vis-à-vis his lawyer (AlMansour, 2016, 771). Therefore (the first requirement) of this topic will discuss the concept of obscene ignorance, and whether the failure to mention the name of the client's opponent in the agency is a form of flagrant ignorance that affects the validity of the judgment issued in the case, and then the legal and judicial position on this issue is studied. the case. Obscene ignorance and its impact on the ruling issued (the second requirement).

\subsection{The First Requirement: Obscene Ignorance in the Agency Contract (The Omission of not Mentioning the Name of the Client's Opponent in the Agency)}

Obscene ignorance is what leads to disagreement and is represented by a defect related to the conditions for the validity of the legal act and results in the invalidity of the act. As for the concept of the opponent's name slipping in the agency, the jurisprudence did not specify his position explicitly towards it, but rather dealt with it within the framework of error, where he defined the error as "a breach of a right or higher." Benefit" (Al-Adawi, 1997, 354), based on the deviation in human behavior with his awareness of this deviation.

The lawyer's written errors are considered professional errors that fall under all pen errors such as omission, forgetting to mention some data or misrepresenting it. The error in describing the judgment may be in absentia or in presence, and the written error may appear in the form of the opponent's silence in the agency, In this case, the litigant does not gain a right as much as possible through the evidence and memoranda presented in the case to 
correct that lapse without negating the litigation ${ }^{12}$. But if the error is in writing, then it is necessary to differentiate here between whether the error in the names of the litigants is so serious that it leads to ignorance of the litigation or not? If the error was so serious that he was ignorant of the litigants or led to confusion in his personality and the truth of his relationship to the case, then the principle of correction cannot be adopted here, but rather by appealing against it in the prescribed manner. By law, because this error leads to the invalidity of the judgment, But if the error in the litigants' names or their characteristics does not make the litigants ignorant or leads to confusion in their personalities and does not affect the integrity of the elements of the judgment, then the solution in this case is to refer to the court that issued the judgment to correct the material error in it ${ }^{13}$. It is permissible to mention the omission in the statement of the claim, as if the name of the client was mentioned in error. In this regard, the Court of Cassation ruled as follows: “... it is considered a slip that does not create a right for others as long as it is the same intended in the case and he does not deny it, so the enmity is between them, and there will be appellant ${ }^{14}$ ". It also ruled: "If the plaintiff expressly stated his claim that his work was with the late, and that his type of work is a horse shoe, and that his workplace is the Jordanian Equestrian Club, does the club belong to the late employer or not is not one of the pillars of the work contract, as the phrase (return) was not mentioned. He) has any legal effect to an explicit denial that he was working for the late, which came absolutely and without adding any other capacity to him, which does not negate that his work was with the late person personally, whether he was the owner of the club as the plaintiff imagined or not, Where it is not intended to prove the late ownership of the club, and that such a slip does not earn the opponent the right ${ }^{15}$.

\subsection{The Second Requirement: The Legal and Judicial Position on not Mentioning the Name of the Opponent in the Agency}

In the absence of legal texts showing the legal impact of the fall in not mentioning the opponent's name in the attorney's agency, the legal trends in the decisions of Jordanian courts, specifically the Jordanian Court of Cassation and administrative courts, varied between cancellation. or not. In a number of their decisions, the Jordanian courts confirmed the validity of this agency and did not consider that the absence of the opponent's name is an outrageous ignorance attached to the agency based on its inclusion in the statement of the case that you are reading. With the agency as one integrated part. While she indicated in her other decisions that the attorney's agency is not valid if the name of the opponent is not mentioned in the attorney's agency.

It should be noted that the latest decisions of the Jordanian Court of Cassation and until the preparation of this research stipulated that the attorney's agency that did not mention the name of the litigant is considered a void agency, and this orientation will be indicated below. ${ }^{16}$

The owners of the first tendency have argued that the agency is valid despite the omission of not mentioning the litigant's name in the agency. The Jordanian Court of Cassation decided in its Decision No. 2140 issued on 11-62013 that the general agency does not require mentioning the litigant, the lawsuit or the particular entrusted to him, but rather It comes with an unspecified general term, and it includes what the principal institutes or what claims are brought against him or that he takes or takes against him in terms of legal or administrative measures, unlike a

\footnotetext{
${ }^{12}$ In this regard, the Court of Cassation ruled that “... the third paragraph of the defendant's name was incorrectly mentioned by proxy in the name (Muhammad) instead of the correct name (Ibrahim), and that the defendants are notified of the lawsuit against the name in which the third paragraph was incorrectly stated, and accordingly the income The third syllable of the name of the defendant in this lawsuit is a type of omission and a clerical error, which does not rise in any way to the level of obscene ignorance by proxy, and it is a kind of omission that does not gain the opponent a right in that, which results in the rejection of the request." Discrimination of Rights No. 2227/2013 (a five-member panel) dated 9/30/2013, Adalah Publications.

${ }^{13}$ It was stated in Cassation Rights (83/99) p. 2256 in 2000, the power of attorney given by each of the two partners in the company to the lawyer to appeal the appraiser's decision, where the two appellants were joined together, as it was found that the power of attorney signed by the first partner is written on it the name of the other partner as a client, and what As long as each agency included the power of attorney for the same agent to appeal the same decision of the appraiser, the lesson in the power of attorney is to sign the appended to it, and ignorance negates it, and the error or omission in mentioning the name of the principal does not earn the opponent a right, and does not require legal and fairness to respond to the two appeals related to them, so the insistence of the appeals court on Her overturned judgment is misplaced (Jordanian Judicial Court of Cassation / Agency).

${ }^{14}$ Discrimination of Rights No. 3018/2008 (a five-member panel) dated 8/7/2009, Adalah Publications.

It also ruled: "...If the correct name of the appellant is Muhannad Ghanem Mas'ud Zureikat and the lawsuit is against Muhannad Ghanim Mas'ud Zureikat, then the difference in the third syllable from the defendant's name contained in the statement of claim is one of the material errors that the Court of First Instance corrected, and it is considered one of the The lapse that does not create a right for others, and since the defendant is the intended target of the lawsuit and he is the debtor of the mortgage deed, the subject matter of which was not denied by the defendant, then he becomes an opponent of the plaintiff in this lawsuit. Discrimination of Rights No. 1952/2006 (Quintet Commission) dated 22/1/2007, Adalah Publications.

${ }^{15}$ Discrimination of Rights No. 3528/2004 (a five-member panel) dated 20/2/2005, Adalah Publications.

${ }^{16}$ Discrimination of Rights No. 7738/2018 (Public Authority) dated 9/5/2019 Qestas Publications.
} 
special agency. In justifying this decision, she confirmed that by referring to "the agency issued by Zakaria Ahmed Maali, who in turn appointed the lawyer, Mr. Wael Khleifat to file this case, we find that, with the evidence of its clear expressions, it indicated that it is intended as a general agency regarding the specifics entrusted to him and the litigation, and that the lesson in Contracts are for purposes and meanings, not for words and predicates, according to the general rule stipulated in Article (214) of the Civil Code, because the general agency does not require mentioning the name of the litigant, the case number, or the particular person entrusted with it, but rather it comes with an unspecified general term, which includes everything that the principal establishes or what lawsuits are brought against him, or legal or administrative measures are taken against him, and accordingly, the power of attorney given to the lawyer is a public agency and not a private one." (Al-Mansour, 2016, 773).

The Administrative Court also followed the example of the Court of Cassation when it decided in its decision No. 406 of February 21, 2017 that "the attorney's agency must include the main data in the civil law and that the agency's absence of one of these data does not affect its validity, and it cannot be said that there is Outrageous ignorance if these data are clearly stated in the lawsuit statement, where the lawsuit statement completes the deficiency in the agency and is read with it as one unit. Failure to mention the name of the defendant in the agency does not mean that it implies ignorance as long as the name is mentioned in the statement of claim, since the agency was done correctly in terms of the signature of the clients, the name from the court, the one who entrusted him, and the name of the defendant was made clear in the statement of claim.

While the owners of the second trend argued that the agency was not valid, due to the omission of not mentioning the name of the opponent in the agency, as the Court of Cassation decided in its decision No. 808 issued on 20-62011 by the majority that the case should be dismissed for the obscene ignorance of a lawyer agency. The court based its decision on the fact that "the agency stipulated that the entrusted with it be known and that the agency in the litigation be specific to its subject, persons and the powers of the authorized agent to arrange its effects in accordance with Articles (833) and (834) of the Civil Code and in line with what has been done by legal jurisprudence. And since the litigation is from public order and the court has the right to raise it on its own, and since the attorney general's office, Nasser Marian, is the attorney for the plaintiffs, in the form contained therein, and the phrases contained therein that did not include the name of the litigant (the defendant) the Greater Amman Municipality Council, as well as the particulars entrusted to him and the numbers of the expropriated pieces of It makes the aforementioned special agency involve obscene ignorance, and that it does not authorize the agent to institute this lawsuit, and therefore the lawsuit submitted in reliance on it is submitted by someone who does not have the right to submit it."

Referring to the latest decisions of the Court of Cassation regarding not mentioning the name of the litigant in the agency, it was stated in the decision of the esteemed Court of Cassation in its General Assembly No. 7738/2018 that the agency that is the subject of the case or the point of appeal is an invalid agency because it does not contain the name of the litigant; It is worth noting that the commission's decision was not issued unanimously, but was issued by a majority. From the researcher's point of view on this particular decision; The researcher considers with respect that the commission or the nine members who headed in this direction have erred in considering the agency to be incorrect, and that the researcher supports what was stated in the violation decision for the members judges Muhammad Al-Ajarmeh and Muhammad Muqnassa, and that the lawsuit was filed on the basis of an agency that fulfilled all its conditions, In addition to this, what was mentioned in previous decisions regarding the validity of the agency if it is linked to the case statement, which is the complementary part of the agency, and therefore the failure to mention the name of the opponent in the agency does not result in obscene ignorance.

From our point of view and by reviewing and analyzing the above judicial decisions and with reference to the provisions of the law, in particular Articles (833), (834) and (835) of the Jordanian Civil Code, as well as taking into account the provisions of the Jordanian Bar Association Law; We find that the jurisprudence regarding not mentioning the name of the litigant in the attorney's agency is a matter of discretion due to the trial court, whose rulings often contradicted between the invalidation of the power of attorney at one time and its acceptance at another time. However, with reference to the decisions of the esteemed Court of Cassation, the division over the behavior of one direction was clear and evident in considering the value of mentioning the opponent's name or not in the attorney's agency, as the group of decisions mentioned above indicated the instability of the Court of Cassation and the Administrative Court on a unified opinion. Therefore, we see that considering the case statement as an integral part of the agency is a good approach and conforms to the rules of justice and legal texts, where the list constitutes the most important part in a statement and mentioning the components and basics of the case, including mentioning the name of the litigant and the particular entrusted to him. We also see that the judiciary's view that the general agency is correct if it is presented in the general form in terms of the particularity entrusted to it and the prosecution of any party facing the agent is a commendable position as it spares the judicial field 
disputes and disagreements that it is indispensable and works at the same time to preserve the court's time and effort. Accordingly, we go with what the first opinion held by saying the validity and integrity of the agency and that it does not fall within the obscene ignorance if the name of the opponent is not mentioned in it on the basis that the statement of claim is an integral part of the attorney's agency, which in turn includes the basics of the case from the name of the client, the opponent and the particulars entrusted to him In addition to a detailed explanation of the facts of the case. This is certainly with great respect to what the esteemed Court of Cassation went in its most recent decisions and to adopt the opinion that the agency is invalid in the event that it is devoid of mentioning the name of the litigant despite the legally and linguistically acceptable opinion contained in this approach.

\section{Conclusion}

In this study, the researcher dealt with the issue of the attorney's agency and the relationship of not mentioning the name of the client's opponent in the agency with the invalidation of the attorney's agency according to the Jordanian law. In the agency contract, the issue of obscene ignorance and the omission of not mentioning the name of the opponent in the attorney's agency and its impact on the invalidity of the agency given to him was also addressed. Therefore, after examining these issues, the research concludes with the following results:

1) The study showed that the agency is one of the necessary contracts, and according to the Jordanian law it is a contract whereby the principal establishes another person in his place in a known permissible behavior, in return for a profit, commission or facilities of whatever nature.

2) The study indicated that one of the most important features of the agency contract is the consent or voluntary expression between the agent and his client.

3) The study indicated that there are many mistakes that the lawyer may fall into in the agency contract, there are intentional and non-intentional errors. About the lawyer an intentional mistake, But if the lawyer's will does not lead to the result (the harm), but rather to the action, then his mistake is not considered intentional. The study also indicated that the error may be normal or professional. The normal error is what the lawyer makes of a material act that in his commission is a violation of the duty of care and care imposed on all people, while the professional error is what is related to the technical assets of the profession. Finally, the error may be grave or easy. A major mistake is the one that is not committed by the least negligent and most ignorant of the people. As for the minor error, it is usually defined as the error that does not occur on the part of a person of average care and care, and it is also called an ordinary error.

4) The study showed that the professional error of the lawyer is represented in his breach of his obligations related to the duty of care, effort and not neglect. As for the required care and its standard, it is obvious that the lawyer differs from the ordinary man in the field of his profession. The care of the common man, and therefore obscene ignorance is considered a professional mistake that the lawyer (the agent) may fall into.

5) The study concluded that if the lawyer makes a mistake in writing in the litigants' names or characteristics, here it is necessary to differentiate between these errors. If the error in the litigants' names or characteristics is not ignorant of the litigants or does not lead to confusion in their personalities and does not affect the integrity of the elements of the ruling, then in this case the solution is to refer to the court that The judgment was issued to correct the material error in it.

6) The study concluded that the omission of not mentioning the name of the opponent is nothing but a slip that the lawyer certainly did not mean in his agency, and the mere failure of a statement in the agency, but it is mentioned in the case statement, this exceeds the lack of a statement that the law requires its availability or the failure of a statement that contradicts the reality, and this definitely does not lead This leads to confusion in the mind of the other opponent or infringement of his rights, and therefore the rules of justice and morality require that they be exceeded.

Based on this, we conclude from our study a number of recommendations that we put before the Jordanian legislator in order to remove the confusion regarding the legal effect of the omission of not mentioning the name of the opponent in the agency. Those recommendations are as follows:

1) Delegating special texts and provisions within the Jordanian civil law related to the issue of obscene ignorance that the lawyer may fall into as an agent in the agency contract, as the current law lacks legislative texts regulating and defining the subject of outrageous ignorance, especially with regard to the extent to which the name of the opponent is mentioned in the regulations related to the agency.

2) The necessity of amending the texts of the law to find a legislative text that provides protection to a third party or the client whose right is attached to the agency, from the legal actions of the agent, in the event of an error on the part of the agent. 
3) Determining precisely the cases that lead to the invalidity of the agency contract, especially in cases of obscene errors committed by the agent, whether intentionally or unintentionally.

4) Interpretation and clarification of the articles related to mentioning the litigant's name in the attorney's agency, for example, Article 834/2 regarding the fact that the validity of the agency does not depend on the consent of the litigant, which raised the controversy between mentioning the litigant's name or his consent for the purposes of saying the validity of the agency or not.

\section{References}

Adawi, C. (1997). The Origins of Obligation: Sources of Obligation (1st ed.). Alexandria: The Knowledge Foundation.

Al-Ani, M. (1965) The Origins of Pleadings and Instruments in the Sharia Judiciary (2nd ed.). Baghdad: Dar AlIrshad Publishing.

Al-Azhari, P. (1997). Jawaher Al-Akleel, A Brief Explanation of Khalil (Vol. 2). Beirut: Issa Al-Halabi.

Al-Bahouti, M. (1982). Scouts of the Mask (Part 4). Beirut: Dar Al-Fikr.

Al-Bustani, A. (1990). Al-Wafi. Beirut: Library of Lebanon.

Al-Kasani, A. (1982). Badaa' Al-Sana'i (2nd ed.). Beirut: Dar Al-Kitab Al-Arabi.

Al-Mansour, A. et al. (2016). The opponent's gag rule doesn't really win him over. Journal of Sharia and Law Studies Studies, (2), 767-780.

Al-Ramli, St. (1938). The End of the Needy Explanation of the Curriculum (Part 4). Cairo: Al-Bab Al-Halabi Press. Al-Razi, M. (1865). Mokhtar Al-Sahah. Beirut: The Modern Library.

Al-Sanhoury, P. (1989). Contracts received on contracting work, agency, deposit and guarding (Part 7). Cairo: Dar Al-Nahda Al-Arabiya Publishing.

Al-Zayli, P. (1314). Explaining the facts, explaining the treasure of minutes (Vol. 4, 2nd ed.). Beirut: Dar Al-Marefa for printing and publishing.

Al-Zuhaili, W. (1984). Islamic Jurisprudence and its Evidence (Vol. 5, 2nd ed.). Beirut: Dar Al-Fikr.

El-Shahawi, S. (2001). Provisions of the Agency Contract in Egyptian and Comparative Legislation. Cairo: AlMaaref Foundation for Printing and Publishing.

Fayoumi, A. (1922). Al-Misbah Al-Munir (Vol. 2). Beirut: The Scientific Library.

Hussein, M. (1993). The Civil Responsibility of the Lawyer towards the Client. Cairo: Arab Renaissance Publishing House.

Ibn Kathir, I. (1400). Interpretation of the Great Qur'an (Part 4). Beirut: Scientific Books Publishing House.

Ibn Manzoor, C. (1290). Lisan Al Arab (Vol. 6). Beirut: Dar Sader.

Mansour, M. (2000). Muhammad Hussein, Medical Responsibility, Civil Liability for Surgeons, Dentists, Pharmacists, Public and Private Hospitals, and Nurses. Alexandria: New University Publishing House.

Nader, H. S. (2015). Obligations of the agent in Jordanian legislation, master's thesis. Middle East University. Jordan.

Noureddine, H., \& Bani Mustafa, M. (2012). Reliance on adversity: a comparative study between jurisprudence and Jordanian law. Islamic and Social Advanced Research Journal, 2.

Ragheb. (1976). Studies in the opponent's center before the civil judiciary. Journal of Legal and Economic Sciences, $18(1), 72-510$.

Shaheen, I. (2013). The extent of the agent's responsibility in the agency contract: a comparative study in Islamic jurisprudence. Alexandria: Dar Al-Fikr Al-Jami'i.

Sultan, A. (2016). Sources of Compliance in Civil Law. Oman: House of Culture for Publishing and Distribution.

\section{Copyrights}

Copyright for this article is retained by the author(s), with first publication rights granted to the journal.

This is an open-access article distributed under the terms and conditions of the Creative Commons Attribution license (http://creativecommons.org/licenses/by/4.0/). 